\title{
Analysis of the Factors that Influence the Mud Farmer Income in Sorkam Barat Subdistrict,Tapanuli Tengah District
}

\author{
S L Pasaribu, YL Henuk, Hasnudi, I Sembiring, N Ginting \\ Animal Production Program Study, Faculty of Agriculture, University of North \\ Sumatera, Medan 20155, Indonesia \\ E-mail: sandrypasaribu1@gmail.com
}

\begin{abstract}
Buffalo cattle are one of the commodities that function as a source of animal protein for the community, as savings, additional income, as labor and manure can be used as fertilizer while providing a source of profit / income for farmers. The purpose of the study was to determine the income of mud buffalo farmers and the factors that influence income in the West Sorkam District, Tapanuli Tengah District. The study was conducted in May-August 2018 using primary data. The method used in data collection is interviewing respondents with the Census Method and analyzed with Multiple Linear Regression using SPSS 16 application tools.

The results showed that the income of mud buffalo farmers in West Sorkam District was influenced simultaneously by the business scale, breeders' age, farmer experience, the number of family and labor dependents with $\mathrm{R}$ square valued at $0.986(98 \%)$. The results of the study showed that the business scale and the number of workers gave a significant influence $(\mathrm{P}<0.05)$ on the income of mud buffalo farmers. The income of buffalo farmers in West SorkamSubdistrict is diverse, with the smallest income being Rp. 370,000/ year with a scale of 2 cattle and the largest is Rp. $68,805,000 /$ year with a livestock business scale of 47 tails.
\end{abstract}

\section{Introduction}

The development of the livestock sub-sector is part of agricultural development that aims to form a resilient culture, which is characterized by the ability to prosper farmers and their ability to encourage the growth of the sector as a whole as a whole [1].

In connection with these matters, it is necessary to develop alternative patterns that have economical business scale that are sufficient to contribute to adequate family income. In the future perspective, people's livestock businesses must focus on developing animal agribusiness not only as a side business but have achieved goals in the family economy. In other words, people's livestock business will be the main source of income (at least) and can provide benefits for meeting family needs, such as economic activities and family businesses [2].

Tapanuli Tengah as one of the districts of North Sumatra has a population of 10,494 buffaloes in 2015. The cattle business in KabupatenTapanuli Tengah is spread in various regions with different population levels. Sorkam Barat Subdistrict is one of the areas of cattle population distribution in the Central Tapanuli Regency where the annual population growth of cattle is 408 , reaching 1,151 in 2015 [3].

\section{Materials and Methods}

2.1 Time and place of research

This research was conducted in May-August 2018. The study was conducted in Sorkam Barat Subdistrict, Tapanuli Tengah District, North Sumatra Province. 
2.2 Methods and research respondents

The method used in the collection of research data is the Census Method, which is a method of collecting data if all population elements are investigated one by one. The respondents of this study consisted of buffalo breeders in Sorkam Barat District, Central Tapanuli District. This research was conducted using a questionnaire to interview a number of buffalo farmers in the Sorkam BaratSubdistrict of Tapanuli Tengah District.

2.3 Data Collection Methods

The data used in this study consisted of primary and secondary data :

Primary data obtained through surface observation and interviews with respondents. Secondary data is data collected from the search of library studies, Central Bureau of Statistics data, and data from other agencies related to research interests.

2.4 Analysis data

Data obtained from interviews in the field are processed and tabulated and then the costs of producing and receiving farmers are known. Then the data is analyzed using the income analysis method and processed with the econometric approach model and explained by descriptive method. According to Soekartawi[4], that to calculate income from buffalo raising activities, it can be calculated using the following formula:

Information:

$$
\mathrm{Pd}=\mathrm{TR}-\mathrm{TC}
$$

$\mathrm{Pd} \quad=$ the total income or profit earned buffalo farmer (rupiah / year)

TR = the total revenue or revenue obtained by the farmer buffalo (rupiah / year)

TC = the cost incurred by buffalo farmers (rupiah / year)

The amount of income is tabulated in a simple way, namely by calculating the farmer's income in the effort to raise buffalo to the income of the family in the research area. Based on the results that have been obtained, then to see the factors that influence farmers' income can be seen by using the Econometry Technique Approach Model using multiple linear regression analysis (a tool of the Statistical Package for Social Sciences (SPSS) software.According to Djalal and Usman[5], the estimation model used:

Information:

$$
\hat{Y}=a+b_{1} X_{1}+b_{2} X_{2}+b_{3} X_{3}+b_{4} X_{4}+b_{5} X_{5}+\mu
$$

$\hat{Y}:$ is the farmer's income ( $\hat{Y}:$ hat) affected various factors in maintaining buffalo (rupiah)

a: is the intercept coefficient (constant)

b1 b2 b3: is the regression coefficient

$\mathrm{X} 1$ : is the scale of business (tail)

$\mathrm{X} 2$ : is the age of the farmer (year)

$\mathrm{X} 3$ : is the experience of raising (years)

$\mathrm{X} 4$ : is the number of family dependents (people)

$\mathrm{X} 5$ : is the number of workers (people)

$\mu$ : are other variables not examined

The variables in the hypothesis are tested simultaneously and partially to find out whether the variable has a dominant influence or not.

a) Simultaneous Test (F-test),simultaneous Test (F test) basically shows whether all the independent variables included in the model have a joint effect on the dependent variable. The basis for decision making (a significant level of 5\%) b) Partial Test (t test),this test aims to determine whether there is a partial (self) effect given given the variable $\mathrm{X}$ to the dependent variable $\mathrm{Yc}$ ) Coefficient of termination (R2), the terminated coefficient serves to find out what percentage of influence is given simultaneously by variable X on variable Y (Imam Ghozali [6]). 


\section{Results and Discussion}

\subsection{Characteristics of Respondents}

The characteristics of respondents in this study include social and economic characteristics. The social characteristics of the farmers analyzed included business scale, breeder's age, farming experience, number of family dependents and number of workers.

\begin{tabular}{|c|c|c|c|}
\hline No & Characteristics of Respondents & $\begin{array}{l}\text { Number of } \\
\text { Respondents } \\
\text { (People) }\end{array}$ & Percentage $(\%)$ \\
\hline \multirow[t]{7}{*}{1} & Business Scale (Tail) & & \\
\hline & $0-10$ & 5 & 22,72 \\
\hline & $11-20$ & 8 & 36,36 \\
\hline & $21-30$ & 6 & 27,27 \\
\hline & $31-40$ & 2 & 9,09 \\
\hline & $41-50$ & 1 & 4,6 \\
\hline & Total & 22 & 100 \\
\hline \multirow[t]{4}{*}{2} & Age of Farmer (Year) & & \\
\hline & Productive & 13 & 59,1 \\
\hline & Non Productive & 9 & 40,9 \\
\hline & Total & 22 & 100 \\
\hline \multirow[t]{6}{*}{3} & Farming Experience (Year) & & \\
\hline & $0-10$ & 10 & 45,45 \\
\hline & $11-20$ & 9 & 40,9 \\
\hline & $21-30$ & 1 & 4,6 \\
\hline & $31-40$ & 2 & 9,09 \\
\hline & Total & 22 & 100 \\
\hline \multirow[t]{5}{*}{4} & Number of family dependents (People) & & \\
\hline & $0-2$ & 1 & 4,6 \\
\hline & $3-4$ & 13 & 59,1 \\
\hline & $5-6$ & 8 & 36,36 \\
\hline & Total & 22 & 100 \\
\hline \multirow[t]{4}{*}{5} & Number of Workers (People) & & \\
\hline & $0-1$ & 17 & 77,27 \\
\hline & $2-3$ & 5 & 22,72 \\
\hline & total & 22 & 100 \\
\hline
\end{tabular}

3.2 Total Production Costs for Buffalo Livestock Business

The total production costs in buffalo business are investment costs or fixed costs, namely depreciation costs (cages, equipment and equipment) and variable costs including the cost of feed, wage / labor costs and medicines calculated annually.

\begin{tabular}{lcccr}
\hline \multirow{2}{*}{ Name of Farmer } & $\begin{array}{c}\text { Business Scale } \\
(\text { Tail })\end{array}$ & \multicolumn{3}{c}{ Total Production Cost (Year) } \\
\cline { 3 - 5 } & & Fixed Cost (Rp) & $\begin{array}{c}\text { Variable Costs } \\
(\mathrm{Rp})\end{array}$ & \multicolumn{1}{c}{ Total } \\
\hline MuksinPasaribu & 17 & 4.000 .000 & 18.075 .000 & 22.075 .000 \\
HabsanGorat & 12 & 2.000 .000 & 8.845 .000 & 10.845 .000 \\
AntoSitumorang & 21 & 3.000 .000 & 18.090 .000 & 21.090 .000 \\
MarubaHabeahan & 4 & 1.000 .000 & 3.710 .000 & 4.710 .000 \\
Domo S Matupang & 27 & 4.000 .000 & 18.120 .000 & 22.120 .000
\end{tabular}




\begin{tabular}{lcrrr} 
Aliasman & 11 & 2.000 .000 & 8.845 .000 & 10.845 .000 \\
HanumPurba & 2 & 0 & 3.630 .000 & 3.630 .000 \\
Sitohang & 17 & 3.000 .000 & 18.075 .000 & 21.075 .000 \\
ZupranPanggabean & 5 & 500.000 & 7.000 .000 & 7.500 .000 \\
Pakpahan & 18 & 3.000 .000 & 18.075 .000 & 21.075 .000 \\
J Sinambela & 29 & 8.000 .000 & 36.120 .000 & 44.120 .000 \\
AidilPasaribu & 3 & 0 & 3.630 .000 & 3.630 .000 \\
B Pasaribu & 3 & 0 & 3.630 .000 & 3.630 .000 \\
Isla Marbun & 47 & 10.000 .000 & 36.195 .000 & 46.195 .000 \\
Amin & 25 & 8.000 .000 & 18.090 .000 & 26.090 .000 \\
SyarfiHutauruk & 33 & 9.000 .000 & 36.150 .000 & 45.150 .000 \\
Zulpikar & 17 & 3.000 .000 & 18.045 .000 & 21.045 .000 \\
A Sigalingging & 22 & 4.500 .000 & 36.090 .000 & 40.590 .000 \\
DoharSamosir & 27 & 6.000 .000 & 36.120 .000 & 42.120 .000 \\
E Manalu & 15 & 4.000 .000 & 18.060 .000 & 22.060 .000 \\
L Sitanggang & 11 & 2.000 .000 & 8.860 .000 & 10.860 .000 \\
Simanjuntak & 34 & 6.000 .000 & 18.105 .000 & 24.105 .000 \\
\hline
\end{tabular}

3.3. Total Production Receipts

The acceptance of people's buffalo cattle business is the total acquisition of the results of the business of buffalo cattle for one year. The total revenue obtained can be seen from the sources of revenue of the buffalo farm business.

\begin{tabular}{|c|c|c|c|c|c|}
\hline \multirow[b]{2}{*}{ Name of Farmer } & \multirow[b]{2}{*}{$\begin{array}{c}\text { Business } \\
\text { Scale (Tail)) }\end{array}$} & \multicolumn{3}{|c|}{ Acceptance (Year) } & \multirow[b]{2}{*}{ Total } \\
\hline & & $\begin{array}{l}\text { Sold Cattle } \\
\text { (Rp) }\end{array}$ & $\begin{array}{c}\text { Livestock } \\
\text { Value Added } \\
(\mathrm{Rp})\end{array}$ & $\begin{array}{l}\text { Dirt Sales } \\
\text { (Rp) }\end{array}$ & \\
\hline M Pasaribu & 17 & 32.000 .000 & 16.000 .000 & 2.000 .000 & 50.000 .000 \\
\hline H Gorat & 12 & 15.000 .000 & 8.000 .000 & $(750.000)$ & 23.000 .000 \\
\hline A Situmorang & 21 & 29.000 .000 & 20.000 .000 & (3.000.000) & 49.000 .000 \\
\hline M Habeahan & 4 & 0 & 8.000 .000 & (0) & 8.000 .000 \\
\hline D Simatupang & 27 & 43.000 .000 & 28.000 .000 & (2.000.000) & 71.000 .000 \\
\hline Aliasman & 11 & 14.000 .000 & 12.000 .000 & $(800.000)$ & 26.000 .000 \\
\hline H Purba & 2 & 0 & 4.000 .000 & $(0)$ & 4.000 .000 \\
\hline Sitohang & 17 & 34.000 .000 & 16.000 .000 & (3.000.000) & 50.000 .000 \\
\hline Panggabean & 5 & 0 & 8.000 .000 & $(0)$ & 8.000 .000 \\
\hline Pakpahan & 18 & 25.000 .000 & 16.000 .000 & (3.000.000) & 41.000 .000 \\
\hline J Sinambela & 29 & 47.000 .000 & 28.000 .000 & 4.000 .000 & 79.000 .000 \\
\hline AidilPasaribu & 3 & 0 & 4.000 .000 & $(0)$ & 4.000 .000 \\
\hline B Pasaribu & 3 & 0 & 4.000 .000 & $(0)$ & 4.000 .000 \\
\hline Isla Marbun & 47 & 75.000 .000 & 40.000 .000 & $(4.500 .000)$ & 115.000 .000 \\
\hline Amin & 25 & 33.000 .000 & 24.000 .000 & 4.000 .000 & 61.000 .000 \\
\hline S Hutauruk & 33 & 45.000 .000 & 32.000 .000 & $(4.500 .0000)$ & 77.000 .000 \\
\hline Zulpikar & 17 & 24.000 .000 & 16.000 .000 & (1.500.000) & 40.000 .000 \\
\hline A Sigalingging & 22 & 34.000 .000 & 16.000 .000 & (1.500.000) & 50.000 .000 \\
\hline D Samosir & 27 & 38.000 .000 & 24.000 .000 & (4.500.000) & 62.000 .000 \\
\hline E Manalu & 15 & 25.000 .000 & 12.000 .000 & (1.000.000) & 37.000 .000 \\
\hline L Sitanggang & 11 & 8.000 .000 & 8.000 .000 & $(750.000)$ & 16.000 .000 \\
\hline
\end{tabular}




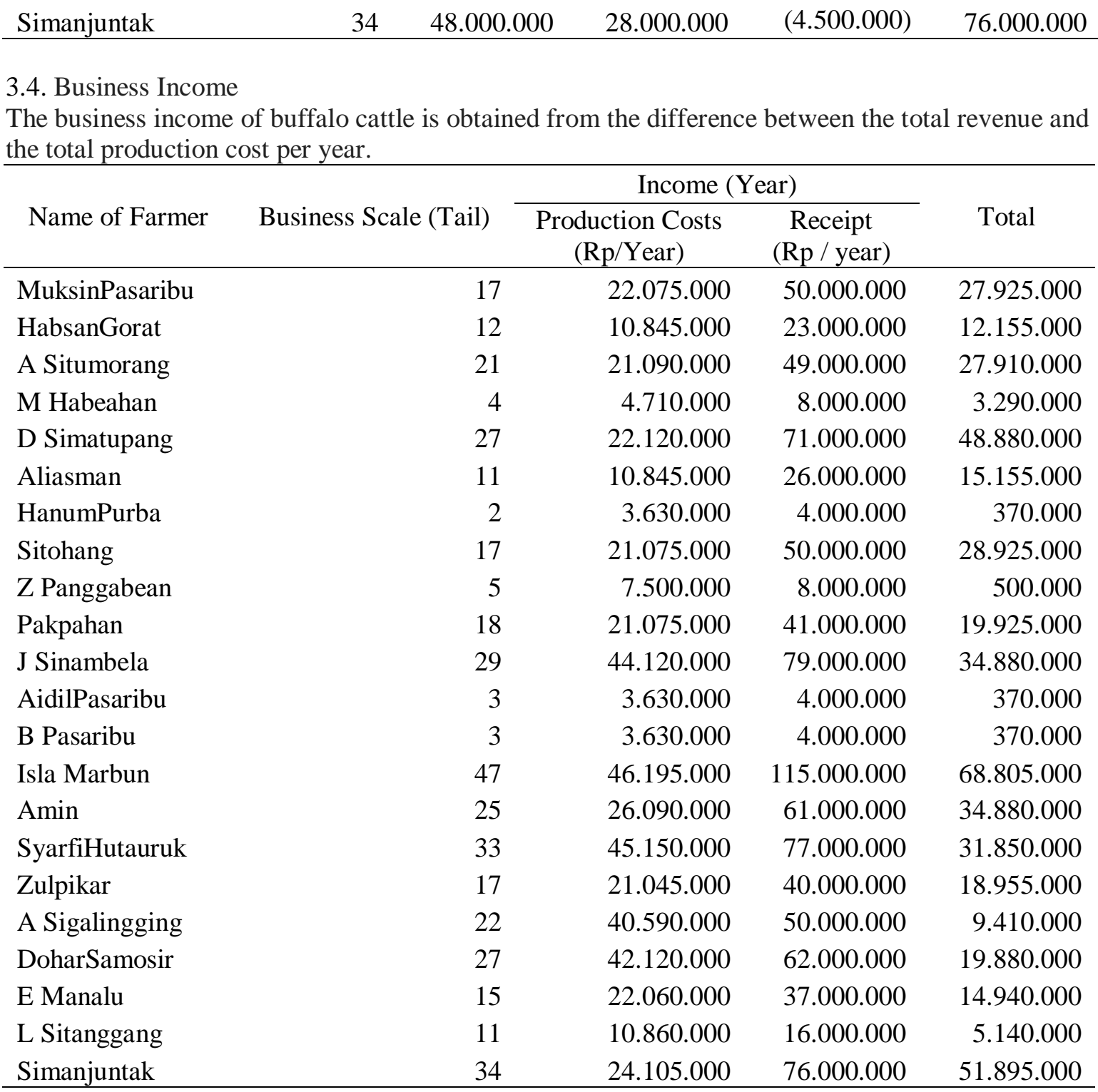

3.5 Effect of Variables Free of Income

The results of testing the factors that influence the income of buffalo farmers in Sorkam Barat

\begin{tabular}{lrrrr}
\hline Variable & \multicolumn{1}{c}{$\begin{array}{l}\text { Regression } \\
\text { Coefficient }\end{array}$} & \multicolumn{1}{c}{ Std. Eror } & $\mathrm{t}$ - Hitung & Significant \\
\hline Konstanta & 17.380 .000 & 6.911 .000 & 2,515 & 0,023 \\
$(\mathrm{X} 1)$ & 1.881 .000 & $143.361,516$ & 13,120 & 0,000 \\
$(\mathrm{X})$ & $95.814,002$ & $108.261,531$ & 0,885 & 0,389 \\
$(\mathrm{X})$ & $10.802,799$ & 147845,905 & 0,073 & 0,943 \\
(X4) & -2.143 .000 & 1.036 .000 & $-2,069$ & 0,055 \\
(X5) & -19.560 .000 & 3.320 .000 & $-5,891$ & 0,000 \\
R Square & 0,953 & & & \\
Regresion & $6.888 \mathrm{E} 15$ & & & \\
Residual & $3.427 \mathrm{E} 14$ & & & \\
F Tabel & 2,81 & & & \\
F Hitung & 64,214 & & & \\
t Tabel & 2,12 & & & \\
\hline
\end{tabular}


Based on the table above the equation is obtained as follows:

$Y=17.380 .000+1.881 .000(X 1)+95.814,002(X 2)+10.802,799(X 3-2.143 .000(X 4)$

$-19.560 .000(X 5)+\mu$

Based on the regression results above can be known:

a. Constant value is $17,380,000$. This means that if the independent variables are business scale, breeder's age, farming experience, number of family dependents, and the number of workers not doing activities, the farmer will get income equal to the constant value of Rp. 17,380,000.

b. $\mathrm{R}$ square value of 0.953 means that all independent variables (business scale, breeder's age, breeding experience, number of family dependents, and number of workers) affect the dependent variable by $95 \%$ and the remaining $5 \%$ is explained by other variables not examined in the study.

c. Simultaneously the value of $F$ count $(64,214)>$ from $F$ table $(2,120)$. This shows that simultaneously the five independent variables namely business scale, breeder's age, farming experience, number of family dependents and the number of workers significantly influence (there is a positive effect) on the income of mud buffalo farmers with a significant level of 0,000 .

d. Partially the value of the t-count variable that affects is business scale variable $(13,120)$ breeder age $(0,885)$ experience of raising $(0.73)$ number of family dependents $(-2,069)$ and number of workers $(-5,891)$.

Based on the above equation model it can be interpreted that:

a. If the independent variable Business Scale (X1) increases by 1 tail, then there will be an increase in income (Y) of IDR 1,881,000.

b. If the Age of Breeders free variable (X2) increases by 1 year, then there will be an increase in income (Y) of Rp. 95,814.002.

c. If the independent variable of the Farming Experience (X3) increases by 1 year, then there will be an increase in income (Y) of IDR 10,802,799.

d. If the independent variable Number of Family Dependents (X4) increases by 1 person, then there will be a decrease in income (Y) of Rp. 2,143,000.

\section{Conclusions}

The income of buffalo farmers in Sorkam Barat Subdistrict varies where the smallest income is Rp. 370,000 / year with the scale of livestock business 2 tails and the largest is Rp. 68,805,000 / year with a business scale of 47 tails. The number of livestock (business scale) and the number of workers is a very influential factor on farmer income, business scale has a positive influence in increasing farmer's income but the number of workers has a negative influence on farmer's income, causing a decrease in farmer's income while the farmer's age, farming experience, and the number of family dependents has no significant effect (does not provide an increase) on farmers' income in Sorkam Barat District, Central Tapanuli Regency.

References:

[1] Bancin, S. 2013. AnalisisPendapatanPeternakSapiPotong di KecamtanSiempatNempu Hulu KabupatenDiari. Medan : FakultasPertanian USU.

[2] Widjaja, K. 1999. AnalisisPengambilanKeputusan Usaha ProduksiPeternakan. Bogor : LembagaPengabdianKepadaMasyarakat.

[3] BadanPusatStatistikKabTapteng. 2016. PopulasiTernakMenurutJenisTernakdanKecamatan di Kab. TapTeng. Pandan : DinasPertanianKabupatenTapanuli Tengah.

[4] Soekartawi .1995. Analisis Usaha Tani. Jakarta : PenerbitUniversitas Indonesia.

[5] Djalal N dan Usman . 2002. PenggunaanTeknikEkonometriEdisiPertama. Jakarta : PT Raja GrafindoPersada.

[6] Ghozali, Imam. 2011. AplikasiAnalisis Multivariate Dengan Program SPSS. Semarang: Badan Penerbit Universitas Diponegoro. 